\title{
THE IMPACT OF INTERVENTION
} PROGRAM ON HEALTH BEHAVIOURS AND SOCIOEMOTIONAL SKILLS AMONG
PORTUGUESE COLLEGE STUDENTS

\author{
Marta Reis, Lúcia Ramiro, Margarida Gaspar de Matos \\ University of Lisbon, Portugal \\ E-mail: reispsmarta@gmail.com, lisramiro@sapo.pt, margaridagaspar@netcabo.pt
}

\begin{abstract}
Health promotion is defined as the process of enabling people to increase control over and to enhance their health. It focuses on individual behaviors towards a wide range of interventions on social and environmental determinants of health and other health related aspects of life (WHO, 2015; 2017). Thus, health promotion implies the need to promote and empower people with resources and skills towards health and well-being (Saboga-Nunes, et al., 2019). The literature reports a negative variation in the lifestyle of university students, and simultaneously demonstrates a significant percentage of university students with a set of emotional, relational, anxiety and stress management difficulties (WHO, 2021, 2018). The need to curb behavioral tendencies harmful to the health of young university students comes justify the need for health promotion in the context of these institutions. This study aimed at analyzing the impact of university students' training, in the area of health promotion and of personal and socio-emotional skills. Participated 286 students. The results show that in addition to the skills worked during the training, the students'well-being and health also improved at the end of the training. The variables that evidenced to be the most important for the university students' health promotion were that they finished the training with more self-esteem, resilience, psychological well-being, self-efficacy, happiness and less instability and alienation. Regarding the pre and post evaluation comparisons about skills, importance and usefulness of HBSC/JUnP training, it was observed that both knowledge about health aspects and personal and socio-emotional skills, namely the resilience, self-regulation and problem-solving strategies had a strong positive impact on promoting the health and well-being of students. Higher education institutions present themselves as enhancers of public health, contributing to the students make healthy choices.
\end{abstract}

Keywords: health promotion, personal and socio-emotional skills, university students' training, healthy universities, Portugal

\section{Introduction}

Health promotion is defined as the process of enabling people to increase control over and to enhance their health. It focuses on individual behaviors towards a wide range of interventions on social and environmental determinants of health and other health related aspects of life (WHO, 2015; 2017). Thus, health promotion implies the need to promote and empower people with resources and skills towards health and well-being (Saboga-Nunes, et al., 2019). The purpose of 
health promotion is to promote and influence healthy behaviors of individuals and communities, create suitable environment that supports healthiness and productivity, and strengthen community actions and efforts to adopt healthy behaviors among people (WHO, 2015; 2017).

Since the Alma-Ata conference (WHO, 1978), investment in health promotion has evolved, along with movements created worldwide, also in Portugal, with healthy schools and cities. Health promoting universities embody recent attention to health policies, in line with the Okanagan Charter (2015).

Health promotion calls on the university students to ensure well-being and quality of life as well as, the training of the university students themselves in the sense of (co)construction of their projects of life, in the terms recommended by Alma-Ata (1978) and Carta de Ottawa (1986). In this regard, and health being transversal to all policies, as well as healthy environments and as a resource that should be available to everyone for the evolution of communities.

Investing in health promotion within the scope of higher education, it was only in 2015 with the Okanagan Charter that the first specific references for health promoting universities emerged, aims to train for characteristics such as strategic thinking, proactivity and innovation, emotional resilience, community experience, commitment to citizenship, particularly in health. Universities can play an important role in health promotion mainly by improving students' health literacy, behaviors and academic achievements.

In this sense, empowering university students with knowledge about health-related aspects (e.g., nutrition, physical activity, contraception, STIs, etc.); main risk and protective factors; personal and socio-emotional skills is the objective for them to develop responsible decision-making, and adopt assertive behavior given the social stimuli inherent to development (Reis, et al., 2018). Therefore, intervention programs should be based on active pedagogical approach, which starts from the acquisition and understanding of information for the development of decision-making skills, with a critical sense, responsibility and autonomy, and not just in a merely informative logic about the risks and prevention of diseases (DGS, 2016).

Socio-emotional skills allow the acquisition of necessary skills so that it is possible to adapt to different situations and day-to-day activities, giving rise to successful young people in their life projects, with their families, at school, in the workplace and in the relationship with others. The promotions of these skills are identified as generators of positive changes in order to make them agents of change. In addition to the evidence in school results, there is also the development of responsibility, autonomy, social and civic participation of all involved (DGS, 2016).

There are factors that favor the construction of internal resources, which are reflected in the individual's intentional actions, becoming promoters of well-being, satisfaction with life and happiness (Borges, 2012; Reis, et al., 2020). Contexts, such as higher education, must adapt strategies and lines of action in order to foster resilience, social and interpersonal skills, optimism, affectiveemotional skills, assertiveness, autonomy in decision-making, and also problem solving (Reis, et al., 2018; 2020).

The move to higher education represents one of the most desired and simultaneously most difficult changes that students experience, along their career path study. It is known that due to the changes of pedagogical nature (resulting from the move to higher education), ecological (resulting from new life contexts) and developmental (related to the performance of development tasks expected for the life stage in which one is in) there will be multiple challenges for university students. The case of changes in the environment in which he starts to live, both at a personal and academic level, the physical distance from the family in many situations, conditioning the mobilization of this environment. In crisis situations, the first steps towards the construction of identity may arise, through decisions and responsibilities that will arise, as well as the development of meaning for life (Reis, et al., 2018; 2020; Soares, et al., 2015).

The literature reports a negative variation in the lifestyle of university students. The consumption of tobacco, alcohol, and drugs, sedentary lifestyle and unprotected sexual behavior are also among the common practices of university students (Reis, et al., 2021; Soares, et al., 2015). The evidence simultaneously demonstrates that a significant percentage of university students with a set of emotional, relational, anxiety and stress management difficulties that are often already preexisting to this admission, but which are evident or worsen in the academic context in a percentage 
OF PSYCHOLOGY

IN THE $21^{\text {st }}$ CENTURY

Vol. 15, No. 2, 2021

84

equivalent to 53\%, are essentially due to the transition phase they are in (Almeida, et al., 2020; Reis et al., 2020).

The need to curb behavioral tendencies harmful to the health of young university students comes justify the reality reflected in the previous data and, thus, justify the need for health promotion in the context of these institutions. According to the WHO (2018) there is a trend in the continuity of risk behaviors acquired during the university period, towards the professional stage. In addition, the health behaviors developed during the period of adolescence and youth have a significant impact on the development of future illnesses.

Ensuring university students, in addition to the right to quality education, the right to a physical and psychosocial environment that facilitates decisions that are more favorable to their health and wellbeing.

Therefore, considering the impact that health can have on university students' lifestyles and well-being, this study aimed at analyzing the impact of university students' training, in the area of health promotion based on the concept of Healthy Universities (https://healthyuniversities.ac.uk/) especially in the promotion of personal and socio-emotional skills.

\section{Research Methodology}

\section{General Background}

The intervention program HBSC/JUnP about health behaviors and socioemotional skills among Portuguese college students aims at the development of personal and social-emotional skills and includes the prevention of symptoms such as anxiety/stress, sadness and worries, as well as the promotion of health, well-being, resilience and self-regulation. It was a nationwide intervention program, with university students aged 18 years and over. The program HBSC/JUnP started in March 2019 and ended in July 2020.

\section{Sample}

The sample consisted of 286 university students distributed throughout the country: 9 groups of young people in Lisbon and Vale do Tejo, 1 group in Algarve and 2 group in Madeira Island. Of the 286 participants, $29 \%$ are male and $71 \%$ female and have an average age of $25.4(S D=6.99)$.

When asked if they were student workers, $42.3 \%$ said yes, of which $56.2 \%$ reported working part-time and $43.8 \%$ full-time.

\section{Table 1}

Demographic Characteristics of the Participants

$\begin{array}{llll}N & \% & M & S D\end{array}$

$\begin{array}{lcccc}\text { Sample } & & & & \\ \text { Gender } & 83 & 29 & & \\ \text { Male } & 203 & 72 & & \\ \text { Female } & 286 & 100 & 25.35 & 6.985 \\ \text { Age } & & & & \\ \text { Regions } & 217 & 75.9 & \\ \text { Lisbon } & 56 & 19.6 & \\ \text { Madeira Island } & 13 & 4.5 & \\ \text { Algarve } & & & \\ \text { Academic degree } & 278 & 97.2 & \end{array}$




\begin{tabular}{lcccc}
\hline & N & $\%$ & M & SD \\
\hline Master degree & 1 & 0.3 & \\
PhD degree & 4 & 1.4 & \\
Other Specializations & 3 & 1 & \\
Student worker & & & \\
Yes & 121 & 42.3 & \\
No & 165 & 57.7 & \\
Working time1 & & & \\
Part-time & 68 & 56.2 & \\
Full-time & 53 & 43.8 & \\
\hline
\end{tabular}

49 projects were developed by the participants, under the supervision of the trainer. Of the 49 projects, 34 were related to the promotion of well-being and quality of life, 14 to the promotion of mental health and 1 related to the development of personal and socio-emotional skills.

\section{Instrument and Procedures}

Measures and variables

The Questionnaire "HBSC/JUnP - Health and FUNtastic Lifestyle" consists of demographic questions, some questions from the "Study Questionnaire - HBSC/JUnP on health behaviors of young Portuguese university students" (2017), by the HBSC/WHO study - Health Behavior in school aged-children (Matos et al., 2014, 2018), by the "General Questionnaire on Well-Being Psychological, short version [QGBEP-R] (Pereira et al., 2018 ), by the "Rosenberg Self-Esteem Scale" (Romano, et al., 2007 ), by the Resilience Scale (Martins, 2005, 2007), by the alienation scale (Tomé, et al., 2019), by the Subjective Happiness Scale [SHS] (Lyubomirsky \& Lepper, 1999), and questions about the interest, importance and usefulness they attributed to the program. It was also asked to indicate the strengths and weaknesses of the program and asked for suggestions for the future.

For the purpose of this study the following variables were selected:

Participants' sociodemographic characteristics, which included sex, age, regions, academic degree and student worker. The Psychological well-being Scale was assessed by the General Questionnaire on Well-Being Psychological, short version [QGBEP-R] (Pereira et al., 2018). The QGBEP-R is composed of six items, some answered in a Likert-type frequency scale, with five answer alternatives, from never to ever; others on a Likert-type scale of intensity, also with five response alternatives, from feeling full of energy to feeling like I had no energy or vitality at all. The value of the scores assigned to items 2,3 , and 6 are inverted, only later is the total psychological well-being score calculated by adding the score of the six items, whose value can vary between zero (0) and thirty (30).

The Self-esteem Scale was surveyed by the Rosenberg Self-Esteem Scale" (Romano, Negreiros \& Martins, 2007) which measures the feelings of respect and acceptance of oneself. Half of the items are stated positively and the other half negatively. For each statement there are four response options (strongly agree $=4$, agree $=3$, disagree $=2$ and strongly disagree $=1$ ). After recoding items 2,5 , 6,8 and 9 , the average of the 10 items gives us the quotation of the total scale whose total score ranges between 10 and 40; getting a higher score reflects high self-esteem.

Resilience was assessed by the Portuguese version of Martins $(2005,2007)$. It is a scale that measures external and internal resources. External resources assess the environment with friends, the academic, family and community. Internal resources measure empathy, problem solving, selfefficacy, cooperation/communication, self-awareness, and goals/aspirations. In this study, only the internal resources subscale was used, since for the author, more than the total of the scale, the subtotals of each subscale allow a specific analysis of potential intervention domains, in order 
OF PSYCHOLOGY

IN THE $21^{\text {st }}$ CENTURY Vol. 15, No. 2, 2021

86

to promote resilience skills higher. The internal resources subscale consists of 18 items, the scale ranges from 18 to 72 points, with higher values to indicate better levels of internal resilience. On this subscale, cooperation/communication, empathy and problem solving are related to social competence resources; self-efficacy and self-awareness are related to the resources of autonomy and sense of self; the goals/aspirations are related to the resources of sense, meaning and purpose (Constantine, et al., 1999).

Alienation was assessed by the Portuguese version, validated in adolescents, has 10 items, the scale ranges from 10 to 50 points, with higher values to indicate worse levels of alienation (see table 2), which must be answered using a five-point Likert scale, ranging from 1 (It's always true) to 5 (It's never true). It is organized into three dimensions (Demotivation; Instability and Isolation). The demotivation dimension is evaluated by a set of 5 items in which the values can range from 5 to 25 points, the instability evaluated by 3 items in which the values can vary from 3 to 15 points and isolation by 2 items where values can range from and 2 to 10 points (Tomé, et al., 2019).

Happiness was assessed using the self-report Subjective Happiness Scale [SHS] (Lyubomirsky \& Lepper, 1999). The happiness scale is a 4 -item subjective happiness scale that measures overall happiness. It is derived from a 7-point Likert scale ranging from 1 to 7 , in which $1=$ not a very happy person and $7=$ a very happy person. The composite score for global subjective happiness is obtained by averaging the responses to all the four items on the subjective happiness scale. The possible score range is from 1 to 7 , higher scores reflecting greater happiness.

Healthy lifestyle was evaluated on a scale from 0 to 10 in which 0 represents the worst and 10 the best option.

\section{Procedures}

The main goal of "HBSC/JUnP" is to develop a university environment that promotes wellbeing and healthy lifestyles among young people. The program aims at the development of personal and social-emotional skills and includes the prevention of symptoms such as anxiety/stress, sadness and worries, as well as the promotion of health, well-being, resilience and self-regulation in a context university.

During training, a program of personal and socio-emotional skills was developed, which included the prevention of symptoms such as anxiety/stress, sadness and worries, as well as the promotion of well-being, resilience, self-regulation and mental health in a context university. A pre and post evaluation was carried out with the young participants, in order to ascertain the importance and impact of the training. After training, the young people developed projects that promote well-being and healthy lifestyles for their university.

HBSC/JUnP training was implemented with students from all courses and all years covering universities from all the regions of Portugal. There have been training groups all over Portugal, namely in the Lisbon, South and Madeira Island regions.

A "pre-post" evaluation was carried out for each training carried out in the intervention program HBSC/JUnP - Promotion of healthy Portuguese Universities.

The first assessment of the study was conducted one week before the start of the training, while the second one was carried out two weeks after the HBSC/JUnP training. Data collection was performed through an online survey, using the Limesurvey platform.

Thereby, it aimed at verifying the real impact of the training among the participants, namely the level of their knowledge about health and their skills to develop the promotion of well-being and healthy lifestyles projects in their university.

The training program consists of 40 hours, distributed for 20 hours theoretical, formal, in person, and 20 "non-face-to-face" hours, practical sessions. The theoretical part addressed several topics, such as: promoting health, risk and protective behaviors, promoting skills, active listening, assertiveness, autonomy in decision-making and also problem solving, self-regulation, resilience, leadership, and entrepreneurship. In the practical part, the participants developed and implemented projects with the technical supervision and evaluation from the HBSC/JUnP technician. The distance learning modules were carried out through the Communication Technologies, mainly via Zoom with sessions between the trainees and trainer. 
The training was planned as follows:

Module 1 - Health Promotion in University; Module 2 - Project Methodology; Module 3 -

Project Design; Module 4 - Project Presentation; Module 5 - Techniques and Strategies for

Project Development; Module 6 - Project Implementation in Universities.

Informed consent was obtained from all individual participants included in the study, and HBSC/JUnP followed all the rules for research outlined in the Declaration of Helsinki (WMA, 2008) and was approved by the Ethics Committee of the Medical Center of Lisbon. Confidentiality was ensured and data access restricted to the research team members.

\section{Data Analysis}

Data from Limesurvey was transferred to an electronic data file. All variables were checked for data inaccuracy by running SPSS frequencies. Subsequently, an analysis on missing values was conducted. All data were tested for normality prior to any analyses using Kolmogorov-Smirnov tests, as well as Levene's test for the homogeneity of the variance. Both descriptive and inferential statistics were applied. All statistical analyses were completed using the SPSS 24.0 (Statistical Package for Social Sciences) and the significance level was set at $p<.05$.

\section{Research Results}

Table 2 shows the internal consistency of the scales under study. For the psychological wellbeing scale, the internal consistency values found were $\alpha=.86$, for the self-esteem $\alpha=.88$ and for the happiness $\alpha=.77$. For the resilience scale, the internal consistency values found were $\alpha=.90$ and for the subscales of resilience, the following values of internal consistency were found: objectives and aspirations $\alpha=.83$, self-awareness $\alpha=.82$, problem solving $\alpha=.79$, self-efficacy $\alpha=.75$, empathy $\alpha=.69$ and cooperation and communication $\alpha=.66$. For the alienation scale, the internal consistency values found were $\alpha=.72$ and the alienation subscales, it was found that: demotivation $\alpha=.77$, instability $\alpha=.66$ and isolation $\alpha=.81$ (see table 2 ).

\section{Table 2}

Internal Consistency of the Scales

\begin{tabular}{llccccc}
\hline \multicolumn{1}{c}{ Factor } & Items & $\boldsymbol{N}$ & $\boldsymbol{M}$ & $\boldsymbol{S D}$ & Cronbach $\boldsymbol{\alpha}$ \\
\hline \multirow{5}{*}{ Resilience } & Psychological well-being & 6 & 572 & 17.71 & 5.15 & .86 \\
\hline \multirow{5}{*}{ Alienation } & Self-esteem & 10 & 572 & 23.38 & 6.69 & .88 \\
& Total scale & 18 & 572 & 55.80 & 7.85 & .90 \\
& Objectives and aspirations & 3 & 572 & 10.80 & 1.54 & .83 \\
& Self-awareness & 3 & 572 & 9.29 & 1.92 & .82 \\
& Problem solving & 3 & 572 & 8.21 & 2.22 & .79 \\
& Self-efficacy & 3 & 572 & 8.74 & 1.83 & .75 \\
& Empathy & 3 & 572 & 9.69 & 1.64 & .69 \\
& Cooperation and communication & 3 & 572 & 9.08 & 1.65 & .66 \\
\hline & Total scale & 10 & 572 & 26.11 & 4.58 & .72 \\
& Demotivation & 5 & 572 & 11.11 & 2.61 & .77 \\
& Instability & 3 & 572 & 9.78 & 1.97 & .66 \\
& Isolation & 2 & 572 & 5.23 & 1.97 & .81 \\
& Happiness & 4 & 572 & 18.33 & 3.55 & .77 \\
\hline
\end{tabular}


OF PSYCHOLOGY

IN THE $21^{\text {st }}$ CENTURY

Vol. 15, No. 2, 2021

88 At the beginning of training, when asked if they consider they have enough personal and socio-emotional skills, $39.5 \%$ say they have some, while $8.4 \%$ of young people consider they have many skills. And the most, young university students consider the HBSC/JUnP training very important for Portuguese universities (52.8\%).

And in the post of $\mathrm{HBSC} / \mathrm{JUnP}$ training, there were statistically significant differences in these two questions $\left(\mathrm{c}^{2}(4)=43.134 ; p<.001 \mathrm{c}^{2}(3)=24.552 ; p<.001\right.$, respectively). There was an increase in the percentage of young people who said they had enough (45.5\%) and many $(10.1 \%)$ personal and socio-emotional skills and also an increase in the number of young people considering the HBSC/JUnP training sufficiently important (34.3\%) and very important (65.7\%).

Table 3

Pre and Post Evaluation Comparisons about HBSC/JUnP Training

\begin{tabular}{|c|c|c|c|c|c|c|}
\hline & \multicolumn{2}{|c|}{ Initial $(N=286)$} & \multicolumn{2}{|c|}{ Final $(N=286)$} & \multirow[b]{2}{*}{$\chi^{2}$} & \multirow[b]{2}{*}{$p$} \\
\hline & $N$ & $\%$ & $N$ & $\%$ & & \\
\hline $\begin{array}{l}\text { Do you think you have enough personal and socio- } \\
\text { emotional skills }\end{array}$ & & & & & 43.134 & $<.001$ \\
\hline None & 3 & 1 & - & - & & \\
\hline Few & 37 & 12.9 & - & - & & \\
\hline Some & 113 & 39.5 & 127 & 44.4 & & \\
\hline Enough & 109 & 38.1 & 130 & 45.5 & & \\
\hline Many & 24 & 8.4 & 29 & 10.1 & & \\
\hline How important is the HBSC/JUnP Training & & & & & 24.552 & $<.001$ \\
\hline Nothing important & - & - & - & - & & \\
\hline Little important & 1 & 0.3 & - & - & & \\
\hline Not too little and not too important & 18 & 6.3 & - & - & & \\
\hline Important enough & 116 & 40.6 & 98 & 34.3 & & \\
\hline Very important & 151 & 52.8 & 188 & 65.7 & & \\
\hline
\end{tabular}

Regarding the results observed in the variables under study using t-Student test, and although there are some variables in which there were no statistically significant differences (e.g., healthy lifestyle, self-awareness subscale and problem-solving subscale), however it was found that after training there was a positive impact in all variables.

There was a statistically significant increase in the following variables: Psychological well-being scale $(M=17.89, S D=5.23)(t(1,570)=-.860 p=.039)$; Self-esteem scale $(M=23.77, S D=6.63)(t$ $(1,570)=-1.389 p=.016)$; Resilience total scale $(M=56.15, S D=8.14)(t(1,570)=-1.044 p=.029)$; and the Self-efficacy subscale $(M=8.84, S D=1.84) t(1,570)=-1.300 p=.019)$; and Happiness Scale $(M=18.48, S D=3.31) t(1,570)=-.784 p=.043)$.

In the Alienation total scale $(M=25.93, S D=4.61) t(1,570)=-.968 p=.033)$; and the Instability subscale $(M=9.69, S D=1.99) t(1,570)=-1.127 p=.026)$; values significantly decreased after training. 
Pre and Post Evaluation Comparisons of the Variables under Study Using $t$-Student (Paired Samples)

\begin{tabular}{|c|c|c|c|c|c|c|c|}
\hline & & \multicolumn{2}{|c|}{ Initial (N=286) } & \multicolumn{2}{|c|}{ Final $(N=286)$} & \multirow[b]{2}{*}{$t$} & \multirow[b]{2}{*}{$p$} \\
\hline & & $M$ & $S D$ & $M$ & $S D$ & & \\
\hline & Healthy lifestyle & 6.73 & 1.54 & 6.78 & 1.58 & -.419 & n.s. \\
\hline & $\begin{array}{l}\text { Psychological well- } \\
\text { being (PWB) }\end{array}$ & 17.52 & 5.07 & 17.89 & 5.23 & -.860 & $.039^{*}$ \\
\hline & Self-esteem & 22.99 & 6.72 & 23.77 & 6.63 & -1.389 & $.016^{*}$ \\
\hline \multirow{7}{*}{ Resilience } & Total scale & 55.36 & 7.54 & 56.15 & 8.14 & -1.044 & $.029^{*}$ \\
\hline & $\begin{array}{l}\text { Objectives and } \\
\text { aspirations }\end{array}$ & 10.80 & 1.51 & 10.80 & 1.58 & -.027 & n.s \\
\hline & Self-awareness & 9.02 & 1.92 & 9.37 & 1.91 & -1.092 & n.s. \\
\hline & Problem solving & 8.07 & 2.20 & 8.24 & 2.24 & -.414 & n.s \\
\hline & Self-efficacy & 8.64 & 1.82 & 8.84 & 1.84 & -1.300 & $.019^{*}$ \\
\hline & Empathy & 9.43 & 1.66 & 9.76 & 1.62 & -.966 & n.s. \\
\hline & $\begin{array}{l}\text { Cooperation and } \\
\text { communication }\end{array}$ & 9.03 & 1.61 & 9.13 & 1.70 & -.707 & n.s. \\
\hline \multirow{5}{*}{ Alienation } & Total scale & 26.30 & 4.55 & 25.93 & 4.61 & .968 & $.033^{*}$ \\
\hline & Demotivation & 11.13 & 2.67 & 11.08 & 2.55 & .240 & n.s \\
\hline & Instability & 9.87 & 1.94 & 9.69 & 1.99 & 1.127 & $.026^{*}$ \\
\hline & Isolation & 5.29 & 1.99 & 5.16 & 1.96 & .805 & n.s \\
\hline & Happiness & 18.21 & 3.77 & 18.48 & 3.31 & -.784 & $.043^{*}$ \\
\hline
\end{tabular}

Table 5 shows the pre and post evaluation comparisons about skills, importance and usefulness of HBSC/JUnP training.

The results showed that in all variables there was an increase in skills, although not all were statistically significant. It was found that there are statistically significant differences in the HBSC/ JUnP intervention program and that after training at $\mathrm{HBSC} / \mathrm{JUnP}$ the young people reported that with participation they will be able to: transmit knowledge about health-related aspects (e.g., nutrition, physical activity, contraception, STIs, etc. $)(M=5.96, S D=0.98)(t(1,570)=-.2 .111 p=.035)$; promote a more positive relationship with my colleagues $(M=6.12, S D=0.80)(t(1,570)=-3.768$ $p<.001)$; promote personal and social-emotional skills in young people $(M=6.14, S D=0.88)(t$ $(1,570)=-5.551 p<.001)$; promote resilience in young people $((M=6.19, S D=0.85)(t(1,570)=$ $-5.232 p<.001)$; promote self-regulation in young people $(M=6.05, S D=0.91)(t(1,570)=-4.933$ $p<.001)$; develop more problem solving strategies $(M=5.97, S D=0.87)(t(1,570)=-2.089 p=.037)$ and develop projects that promote well-being and health at the University $(M=5.84, S D=1.15)(t$ $(1,570)=-3.214, p<.001)$. 
Table 5

Pre and Post Evaluation Comparisons about Skills, Importance and Usefulness of HBSC/JUnP Training

\begin{tabular}{|c|c|c|c|c|c|c|}
\hline \multirow{2}{*}{$\begin{array}{l}\text { With the participation in the HSBC/JUMP } \\
\text { training: }\end{array}$} & \multicolumn{2}{|c|}{ Initial $(N=286)$} & \multicolumn{2}{|c|}{ Final $(N=286)$} & \multirow[b]{2}{*}{$t$} & \multirow[b]{2}{*}{$p$} \\
\hline & M & $S D$ & $M$ & $S D$ & & \\
\hline $\begin{array}{l}\text { Be able to transmit knowledge about health- } \\
\text { related aspects (e.g., nutrition, physical activity, } \\
\text { contraception, STIs, etc.) }\end{array}$ & 5.78 & 1.117 & 5.96 & 0.978 & $-.2 .111^{*}$ & .035 \\
\hline $\begin{array}{l}\text { Identify when a colleague is experiencing a } \\
\text { problematic situation }\end{array}$ & 5.78 & 1.090 & 5.84 & 1.117 & $-.635^{\text {n.s. }}$ & .526 \\
\hline $\begin{array}{l}\text { Promote a more positive relationship with my } \\
\text { colleagues }\end{array}$ & 5.79 & 1.201 & 6.12 & 0.802 & $-3.768^{* * *}$ & $<.001$ \\
\hline $\begin{array}{l}\text { Promote personal and social-emotional skills in } \\
\text { young people }\end{array}$ & 5.65 & 1.206 & 6.14 & 0.877 & $-5.551^{* * *}$ & $<.001$ \\
\hline Promote resilience in young people & 5.74 & 1.172 & 6.19 & 0.848 & $-5.232^{* \star *}$ & $<.001$ \\
\hline Promote self-regulation in young people & 5.61 & 1.223 & 6.05 & 0.907 & $-4.933^{* * *}$ & $<0.001$ \\
\hline Develop more problem-solving strategies & 5.78 & 1.221 & 5.97 & 0.872 & $-2.089^{*}$ & .037 \\
\hline Being able to deal more effectively with stress & 5.92 & 1.186 & 6.03 & 0.942 & $-1.249^{\text {n.s. }}$. & .212 \\
\hline Become more optimistic & 5.63 & 1.380 & 5.62 & 1.221 & $.096^{\text {n.s }}$ & .923 \\
\hline $\begin{array}{l}\text { Being able to effectively help/refer young } \\
\text { people who need specialized help }\end{array}$ & 5.78 & 1.160 & 5.89 & 1.067 & $-1.200^{\text {n.n. }}$ & .230 \\
\hline $\begin{array}{l}\text { Develop projects that promote well-being and } \\
\text { health at the University }\end{array}$ & 5.50 & 1.316 & 5.84 & 1.151 & $-3.214^{* * *}$ & $<.001$ \\
\hline $\begin{array}{l}\text { Promote healthy behaviors among young } \\
\text { people }\end{array}$ & 5.65 & 1.302 & 5.64 & 1.124 & $.103^{\text {n.s. }}$ & .918 \\
\hline
\end{tabular}

\section{Discussion}

The move to higher education represents one of the most desired and simultaneously most difficult changes that students experience, along their career path study. The literature reports a negative variation in the lifestyle of university students, and simultaneously demonstrates a significant percentage of university students with a set of emotional, relational, anxiety and stress management difficulties (WHO, 2021, 2018). The need to curb behavioral tendencies harmful to the health of young university students comes justify the need for health promotion in the context of these institutions.

The HBSC/JUnP training goal is to deepen health behaviors and promote healthy lifestyles of Portuguese university students, through the development of personal and social-emotional skills and includes the prevention of symptoms such as anxiety/stress, sadness and worries, as well as the promotion of well-being, resilience, self-regulation and mental health in a context university.

The importance of university students training was visible in the final results, not only in acquiring the training skills worked but also in students' health and well-being.

Results show that in addition to the skills worked during the training, the students' well-being and health also improved at the end of the training. The variables that evidenced to be the most important for the university students' health promotion were that they finished the training with more self-esteem, more resilience, more psychological well-being, more self-efficacy, more happiness and less instability and less alienation. These variables revealed greater influence than the other variables.

Regarding the pre and post evaluation comparisons about skills, importance and usefulness of HBSC/JUnP training, it was observed that both knowledge about health aspects and personal and socio-emotional skills, namely the resilience, self-regulation and problem-solving strategies had a strong positive impact on promoting the health and well-being of students. 
These results corroborate studies that refer to the importance of personal and socio-emotional skills in promoting well-being and health (Almeida, et al., 2020; Saboga-Nunes, et al., 2019; Soares, et al, 2018; Task Force das Ciências Comportamentais, Branquinho, \& Gaspar, 2021). However, it is also necessary to work on confidence and self-esteem levels in order to maintain students' motivation and their psychological flexibility to overcome less positive events in their lives. Because motivated and satisfied students are at less risk of developing psychological and physical problems (Reis, et al., 2020; 2021).

It should also be noted that the training started before the COVID-19 pandemic but happened and ended during the beginning of the pandemic in Portugal (March to July 2020). All the more reason to consider that the results of the impact of the intervention program are extremely positive, given the distressing world situation. We are experiencing an unexpected situation with the COVID 19 pandemic, more than ever it is important to be aware of the impact on the university students' health and the well-being in the university context.

There are some limitations that should be considered when interpreting these findings. First, measures were self-reported and may reflect biases, especially underreporting of sensitive information. Second, the data represented students in university and may not be generalized to Portuguese young people or those who do not attend university. Third, the study did not assess other potential factors or mediators that may have been important in the associations examined.

Despite these limitations, the findings from this study clearly demonstrate the importance of investing in the prevention of mental health and its determinants in a university context. Moreover, it appears that there are shared and unique factors that may be incorporated in future research and prevention programs. Unfortunately, public health prevention strategies that specifically address health behaviors and mental health in populations of college students are not available in Portugal.

Despite the increased interest and pursuit of research into mental health and socioemotional skills, many aspects remain relatively poorly understood. As such, future research is clearly needed to better understand and respond to the growing need of youth in university context. A recommendation for future data collections is to incorporate measures of mental health, particularly among children, adolescents and young adults so that the prevalence and epidemiology of mental health can be studied across a range of populations and settings. Finally, while mental health is clearly a complex and multi-faceted problem, efforts that seek to understand this issue better and that find ways to develop prevention and intervention strategies are sorely needed, especially in this current situation with the covid-19 pandemic.

\section{Conclusions and Implications}

Higher education institutions present themselves as enhancers of public health, health promotion and sustainable development, contributing to the construction, dissemination and application of knowledge. From a community perspective, these institutions can positively influence the lives of those who study, work and (live) in them, that is, if there is investment in the creation of safe, healthy and sustainable environments. As such, it is expected that these institutions will be able to maximize performance, investing in the empowerment of their community, in the productivity and satisfaction of university students, determinants in today's competitive market.This investment will allow university students, in the exercise of their individual and social responsibility for health, to make healthy choices in their day-to-day lives and commit to defending global health in the long term, through the exercise of citizenship or the performance of roles with impact on future health policies or decision-making on them.

The challenge of the covid-19 pandemic and this very recent study demonstrate the need for intervention measures in higher education, namely implement programs to promote health, healthy lifestyles and programs to promote social-emotional skills for the whole academy community (classroom teaching and / or online training);implement and/or adapt to new needs of psychological support and counseling (presential and/ or online); and identify and develop responses to students, teaching and non-teaching staff in vulnerable situations. 
OF PSYCHOLOGY

IN THE $21^{\text {st }}$ CENTURY

Vol. 15, No. 2, 2021

\section{References}

Almeida,T. C., Heitor, M. J., Santos, O., Costa, A., Virgolino, A., Rasga, C., Martiniano, H., \& Vicente, A. (2020). Final report: SM-COVID19-Mental health in times of pandemic. INSA/ISAMB/SPPSM/FCT.

Borges, A. (2012). Contextos, competências e bem-estar dos adolescentes [Contexts, skills and well-being of adolescentes]. In Matos, M. G., \& Tomé, G. (Eds.), Aventura Social: Promoção de Competências e do Capital Social para um Empreendedorismo com Saúde na Escola e na Comunidade [Social adventure: Promoting skills and social capital for an entrepreneurship with health in school and community] (pp. 43-60). Placebo, Editora LDA.

Constantine, N. A., Benard, B., \& Diaz, M. (1999). Measuring protective factors and resilience traits in youth: The healthy kids resilience assessment. Paper presented at the Seventh Annual Meeting of the Society for Prevention Research, New Orleans, LA.

DGS - Direção-Geral da Saúde (2016). Saúde Mental em Saúde Escolar [Mental health in school health]. Manual para a Promoção de Competências Socioemocionais em Meio Escolar [Manual for the promotion of socio-emotional skills in school environment]. Lisboa.

Lyubomirsky, S., \& Lepper, H. S. (1999). A measure of subjective happiness: Preliminary reliability and construct validation. Social Indicators Research, 46(2), 137-155.

Matos, M. G., \& equipa Aventura Social (2018). Relatório do estudo HBSC 2018 - A saúde dos Adolescentes Portugueses Após a Recessão - Dados nacionais do estudo HBSC 2018 [HBSC 2018 study report - The health of Portuguese adolescents after the recession - national data from the HBSC 2018 study]. http://aventurasocial.com/publicacoes/publicacao_1545534554.pdf

Matos, M. G., Simões, C., Camacho, I., Reis, M., \& equipa Aventura Social (2014). Relatório do estudo HBSC 2014 - A saúde dos Adolescentes Portugueses em tempos de Recessão - Dados nacionais do estudo HBSC 2014 [HBSC 2014 study report - The health of Portuguese Adolescents in times of Recession - National data from the 2014 HBSC study]. http://aventurasocial.com/arquivo/1437158618_RELATORIO\%20 HBSC\%202014e.pdf

Martins, M. H. (2005). Contribuições para a análise de crianças e jovens em situação de risco-Resiliência e Desenvolvimento [Contributions for the analysis of children and adolescents in risky situations - resilience and development]. PhD Thesis in Educational Psychology, Faculdade de Ciências Humanas e Sociais da Universidade do Algarve.

Martins, M. H. (2007). Resiliência: para além da diversidade e do risco. [Resilience: Beyond diversity and risk]. Actas do II Congresso Família, Saúde e Doença, Modelos, Investigação e Prática em diversos contextos de Saúde. Universidade do Minho.

Okanagan Charter (2015). An International Charter for Health Promoting Universities and Colleges. International Conference on Health Promoting Universities and Colleges / VII International Congress. Kelowna, British Columbia, Canada. http://hdl.handle.net/2429/54938

Pereira, M. C., Antunes, M. C., Barroso, I. M., Correia, T., Brito, I., \& Monteiro, M. J. (2018). Adaptation and validation of the Psychological General Well-Being Index: Confirmatory factor analysis of the short version. Revista de Enfermagem Referência, IV(18). https://doi.org/10.12707/RIV18001

Reis, M., Gomez-Baya, D., Ramiro, L., \& Matos, M. G. (2020). Relationships between anxiety and aggressiveness in a national sample of Portuguese youth: A moderated-mediation model of long-term and short-term self-regulation by internal resources for resilience, gender and age. Journal of Education Research and Behavioral Sciences, 9(2), 1-12.

Reis,M., Ramiro,L., Gomez-Baya,D.,\&Matos,M.G.(2018). Thepromotionofhealthyuniversities:Asystematicreview. CPQ Women and Child Health, 1(3), 01-15. https://www.cientperiodique.com/article/CPQWC-1-3-16.pdf

Reis, M., Ramiro, L., Paiva, T., \& Matos, M. G. (2021). National Survey on the importance of sleep in the quality of academic life and mental health of college students in Portugal. Sleep Science. https://doi.org/10.5935/1984-0063.20200090

Romano, A., Negreiros, J., \& Martins, T. (2007). Contributos para a Validação da Escala de Auto-Estima de Rosenberg Numa Amostra de Adolescentes da Região Interior Norte Do País [Contributions to the validation 
of the Rosenberg Self-Esteem Scale in a sample of adolescents from the North Interior Region of the country]. Psicologia, Saúde \& Doenças, 8(1), 107-114. https://www.redalyc.org/pdf/362/36280108.pdf

Saboga-Nunes,L., Bittlingmayer, U., \& Okan, O. (2019). Salutogenesis and health literacy: The health promotion simplex! In Okan et. al. (Eds), International handbook of health literacy. Research, practice and policy across the lifespan (pp.649-664). The Policy Press, University of Bristol.

Soares, A., Pereira, A., \& Canavarro, J. (2015). Promoção da Saúde nas Instituições de Ensino Superior Portuguesas: Reflexões e Desafios [Health promotion in Portuguese higher education institutions: Reflections and challenges]. Revista Portuguesa de Pedagogia, 49(2), 115-137. https://doi.org/10.14195/1647-8614_49-2_6

Task Force das Ciências Comportamentais, Branquinho, C., \& Gaspar, T. (2021). Relatório Inquérito às IES Medidas - COVID-19 [HEI Survey Report - Measures - COVID-19]. https://www.dges.gov.pt/sites/ default/files/Inquerito_IES_Acompanhamento_de_Estudantes-COVID_TF_CC_2021.pdf

Tomé, G., Gaspar, T., Branquinho, C., Oliveira, M. L., \& Matos, M. G. (2019). A alienação social e o seu impacto no bem-estar dos adolescentes portugueses [Social alienation and its impact on the wellbeing of Portuguese adolescentes]. Revista de Psicologia da Criança e do Adolescente, 10(1), 229-239. https://doi.org/10.34628/v6ed-1937

WHO - World Health Organization (1978). Declaration of Alma-Ata: International Conference on Primary Health Care. Geneva. https://www.who.int/publications/almaata_declaration_en.pdf

WHO - World Health Organization (2015). Health Cities - Good Health is Good Politics: Toolkit for local governments to support healthy urban development. Geneva. https://www.who.int/westernpacific/ about/how-we-work/programmes/health-promotion

WHO - World Health Organization (2017). Health promoting schools: experiences from the Western Pacific Region. Geneva. https://www.who.int/westernpacific/about/how-we-work/programmes/healthpromotion

WHO - World Health Organization (2018). Fact Sheets on sustainable development goals: Health targets - Mental Health. https://www.euro.who.int/_data/assets/pdf_file/0017/348011/Fact-sheet-SDG-Mentalhealth-UPDATE-02-05-2018.pdf

Cite as: Reis, M., Ramiro, L., \& Matos, M. G. (2021). The impact of intervention program on health behaviours and socioemotional skills among Portuguese college students. Problems of Psychology in the $21^{\text {st }}$ Century, 15(2), 82-93. https://doi.org/10.33225/ppc/21.15.82

\begin{tabular}{|c|c|}
\hline $\begin{array}{r}\text { Marta Reis } \\
\text { (Corresponding author) }\end{array}$ & $\begin{array}{l}\text { PhD, Clinical and Health Psychologist, Researcher, Faculty of Human Kinetics, \& } \\
\text { ISAMB/Faculty of Medicine, University of Lisbon, Portugal. } \\
\text { E-mail: reispsmarta@gmail.com } \\
\text { Website: https://aventurasocial.com/ } \\
\text { ORCID: https://orcid.org/0000-0002-9351-6617 }\end{array}$ \\
\hline Lúcia Ramiro & $\begin{array}{l}\text { PhD, Teacher, Researcher at ISAMB/ Faculty of Medicine, University of Lisbon, Portugal } \\
\text { E-mail: lisramiro@sapo.pt } \\
\text { Website: www.aventurasocial.com } \\
\text { ORCID: https://orcid.org/0000-0002-0065-1757 }\end{array}$ \\
\hline $\begin{array}{r}\text { Margarida Gaspar de } \\
\text { Matos }\end{array}$ & $\begin{array}{l}\text { PhD, Full Professor, Clinical and Health Psychologist, Researcher, ISAMB/ Faculty } \\
\text { of Medicine, University of Lisbon, Portugal. } \\
\text { E-mail: mmatos@fmh.utl.pt } \\
\text { Website: www.aventurasocial.com } \\
\text { ORCID: https://orcid.org/0000-0003-2114-2350 }\end{array}$ \\
\hline
\end{tabular}

